\title{
Sustainable Development and Achieved Success Stories in Competitiveness: Evidences from Arab Countries
}

\author{
Mansour Lotayif ${ }^{1}$ \\ ${ }^{1}$ Applied Science University (ASU) Kingdom of Bahrain \& Beni-Suef University, Egypt \\ Correspondence: Mansour Lotayif, Applied Science University (ASU) Kingdom of Bahrain \& Beni-Suef \\ University, Egypt. E-mial: Mansour.lotayif@asu.edu.bh; Mansourlotayif@hotmail.com
}

Received: May 26, 2019

doi:10.5539/ijbm.v14n8p117

\begin{abstract}
The current research focuses on competitiveness's status of each Arabic country, as indicated at the GCI (Global Competitive Index) report. Its 12-main indicators and 98 sub-indicators have deployed for that mission. Via longitudinal study, the performance of each Arabic country, as indicated on GCI at 2016 and 2018, was carefully analyzed. The analysis revealed that four countries were improved and the rest were not. In addition, the analysis revealed 13 success stories. More specifically, the analysis revealed that Kingdom of Bahrain, KSA, UAE, and Lebanon have two, four, six, and one success stories respectively. For mutual benefits, these success stories ought to be shared with all Arabic countries. Kingdom of Bahrain success stories were in labor market, and innovation capacity indicators. KSA success stories were in macro-stability, skills, market size, and business dynamism indicators. UAE has six success stories in institutions, infrastructures, ICT adoption, macro-economic stability, product market, and financial system indicators. Lebanon has one success story in health indicator. Finally, conclusions and recommendation were suggested to help assist decision markets in this perspective.
\end{abstract}

Keywords: sustainable development, Global Competitive Index (GCI), Arab Countries

\section{Introduction}

Competitiveness is still a concept that ones can read in different ways, although it is widely accepted for its importance (Krugman, 1994) for economic growth and sustainable development. In fact, the emergence of globalization in the global economy and the consequent increase in competition between countries have demonstrated the urgent need for a theoretical definition of competitiveness (Staníčková \& Lenka, 2018). Competitiveness can be defined as an area of economic knowledge that analyzes the facts and policies for state's ability to create a healthy business environment that in turn create sustainable benefit for both enterprises and citizen's prosperity in long term, (IMD, 2012). Therefore, it measures how a country manages its resources and real competences for the welfare of its citizens.

Since its founding in 1971 as a non-profit organization and until it was officially recognized by Swiss law in 2015, the World Economic Forum (WEF) has worked to achieve two goals: to improve competitiveness around the world with the GCI annual report and the organization of Davos annual economic forum. Therefore, the GCI could be defined as an optional, dynamic, and competitive world tournament (WT). It is very similar to the Olympic Games (in which athletes compete in 28 sports each four years) that cover all economic, social, health, physical, and innovative aspects of a country. The registration in this WT is optional, because it does not force any country to participate in it. The willing country is the one that progresses voluntarily and provides economic evidences in this perspective to GCI authorities. Thus, the number of competing countries varies from year to year. For example, the countries participating in the current year (2018) are 140 countries, while 135 and 138 countries were in 2017 and 2016, respectively. Moreover, GCI is very dynamic, as the numbers of the main and sub-indicators used to measure country's performance is changeable. For example, the 12 key indicators used to measure competitiveness were divided into four groups this year (i.e. 2018), while it was only three in previous years (i.e. 2017), as shown by Figure 1 and Figure 2 (Lotayif, 2018). The number of sub-indicators that were 114 indicators, decreased to 98 indicators this year (i.e. 2018) by adding and deleting indicators, as clarified later. Finally, it is a revealing and reflective competition for all development efforts of competing countries.

Countries that seek long-term sustainable development must transfer that to welfare of their citizens. Welfare means the improvement in the standard of living of inhabitants, the increase in purchasing power, and 
improvement in the macroeconomic climate with its various aspects. In its mission for development, GCI report translates these efforts into numerical scaling-scheme and then creating a descending order for the countries of the world. Literally if well conducted, any development effort will positively improve the ranking of the country on the competitiveness index. Therefore, it can be said with confidence that if the development efforts of a country are not reflected in improving its position on the index, it is like someone who plows through the sea and has to review its plans in that regards.

\section{Literature Review}

It worth mentioning that sustainable development (SD) still a debatable area, debatable from its common definition to its components, guidelines, and mechanism. Definition wise, there is no accepted definition of SD and there is no common guidelines to decision makers yielded from stablished definitions (Schmandt \& Ward, 2000). Saeed and Abdeldayem, (2019), Faur et al. (2017); Isabel, and Jose, (2013); Schmandt, and Ward, (2000); and Prugh et al. (2000) have defined sustainable development by stressing many pillars. (1) In efficient usage pillar, SD is the efficient way of using country's resources to meet the needs of both present and future generation. (2) Considering renewability in resources, SD is the appropriate using of renewable natural resources at rates below their regeneration capacity, coupled with the optimal use of non-renewable resources. (3) In considering the substitution usage of commodities, SD is the appropriate usage of current resources and taking into account their substitution provided by technological progress. (4) Mankind perspective, SD is how to maximize the long-term net benefits to humankind, taking into account the costs of environmental degradation. (5) Considering the other dimensions of sustainability, SD is not only technical but also primarily cultural and political process. (6) Sustainable development from religious perspective.

By examining the GCI literature, the competitiveness index has become the focus of many researchers around the globe as it became an objective way of assessment for countries' capabilities and efforts of successful development. It used to assess many emerging economies around the world; for example, it used to analyze the competitiveness status of the Slovak Republic and the other 11 member states of the European Union from Central and Eastern Europe. In addition, it used to analyze the process of development in BRICS countries (i.e. Brazil, the Russian Federation, India, China, and South Africa), in the European Union (EU), in Japan, and in the United States of America. Annex, the index also used to make competitiveness comparisons between the Czech Republic, Hungary, Slovenská Republic, and Poland. In Africa context, the index has deployed to assess and compare the economic performance of Sub-Saharan Africa (SSA) countries. Moreover, the index utilized to assess the economic improvement resulted from conducted reform programs in Serbia. Finally, it was used to identify the competitiveness of the Western Balkans in the global economic crisis (Ivanová \& Čepel, 2018; Staníčková \& Fojtíková, 2018; Kiselakova et al., 2018; Krstić et al., 2016; Krstic et al., 2016; Bondareva \& Tomčík, 2015; Krstić \& Džunić, 2013).

More specifically, in the Slovak and Czech case, comparisons were made between the two countries on the old competitiveness index, which divides the 12 indicators into three sets; basic requirement; efficiency improvement; innovation and development with 114 sub-indicators. Economically, the two countries are similar. Due to that similarity, comparisons were made in accordance with the values of each main and sub-indicator on the competitiveness index. The study ended with a set of recommendations to improve the competitive situation in the two countries (Tomarek \& Bondariva, 2011). On the new index at 2018, the Slovak case was discussed, again, by testing the relationship between research spending, R\&D development, and competitive capacity development. In the same study, the relationship between spending on practical research and the competitiveness of the Central and Eastern European countries (i.e. 11 countries) were examined. The study revealed that any increase in research and development expenditures, especially education, leads to enhancing the competitive advantages (Kiselakova et al., 2018).

Moreover, at the level of comparisons between major trade blocs, competitive comparisons were made between the emerging powers of BRICS and the traditional forces of the United of States America (USA), the European Union (EU), and Japan. The development of the productive capacities of BRICS countries, EU, Japan, and USA were analyzed thoroughly. The results confirmed the superiority of the post-war trinity (i.e. EU, USA, and Japan) compared to the rapid development of the BRICS (Staníčková \& Fojtíková, 2018).

In the same vein, the innovation ecosystem (with its 18 sub-indicators) has used to compare the four widely similar economies i.e. Czech, Poland, Hungary, and Slovakia. The results of that research have shown that these economies are transitional economies in terms of their economic development. Nevertheless, in the global competitive ranking, their locations varies depending on innovative performance. For example, the Czech 
economy is the best performer among the four then Slovak economy has become second and the last one was Hungary economy. The Polish economy is relatively a balanced one (Ivanová \& Čepel, 2018).

As for Balkan countries, their economies were analyzed with focus on knowledge economy. The results confirmed the significant relationship between national competitiveness and speeding on knowledge economy. In addition, Serbia ranking on GCI were checked for five consecutive years from 2009-2014 and compared with other Western Balkan countries (Krstić \& Džunić, 2013).

The results of the comparative study showed that Serbia achieved an enviable level of competitiveness in the period mentioned above (Krstic et al., 2016B). Finally, in Africa, the impact of competitiveness on travel and tourism, measured by Travel and Tourism Competitiveness Index (TTCI), of Sub-Saharan Africa was examined. The results showed that competitiveness in travel and tourism had a significant impact on national competitiveness in Sub-Saharan Africa (SSA) Countries (Krstic et al., 2016A).

As previously indicated, the level of competitiveness a country has is a key factor with consequences on long-term sustainable development. Therefore, the current research adopts the same methodology by comparing the level of competitiveness amongst Arab countries. Therefore, seeking answers for the following legitimate questions are the current research objectives:

1) Are GCI number of indicators the same without changes?

2) What are the improved Arab countries? What are the Arab countries that did not improve?

3) What are the achieved success stories to be shared amongst Arab countries?

4) Finally, what are the practical recommendations that help improve Arabs ranking in the coming GCI?

\section{Methodology}

Literally, methodology includes the adopted paradigm (i.e. positivism, phenomenology, and triangulation), the analytical techniques (i.e. descriptive, bi-variant, and multi-variant analyses), population and sample, response base, response rate, types of data used (i.e. secondary or primary), data collection tools, data reliability, validity, normality, linearity, and multi-collinearity (Lotayif, 2018, 2017, 2016, 2004A; 2004B). In the current research, the adopted paradigm that reflects the basic orientation of the theory and research is phenomenological or qualitative and descriptive approach. The analytical technique is descriptive, the population is 22 Arab countries, the sample is 13 counties that appeared on GCI report at 2018, and data source is the secondary data published at GCI report at 2018 and 2016. The other methodological issues are not related to the current study, as it is descriptive and qualitative one.

To answer the above-mentioned questions, the current research has divided into five main parts, as follows:

1) The updated twelve indicators in GCI report and their methods of measurement.

2) Comparing amongst Arab countries (indicator-based comparisons).

3) Countries that have improved compared to the previous classification.

4) Recommendations that provide a way for decision-makers in Arab countries.

(1) The updated twelve indicators in GCI report at 2018 and their methods of measurement

Although the updated GCI report (i.e. GCI 2018) uses the same number of basic indicators (i.e. 12 indicators), its internal divisions and sub-indicators differ, as shown in Figure (1-2). It is divided into four groups instead of three, as in the 2017 index. These four key indicators include:

1) Enabling environment that includes institutions, infrastructures ICT adoption, and macro-economic stability.

2) Human capital that includes health and skills indicators.

3) Market indicators that include product market, labor market, financial system, and market size.

4) Innovation and ecosystem that includes business dynamism and innovation capacity.

(1) Institutions indicator measured by 20 sub-indicators that includes organized crime, homicide rate, tourism ratio, confidence in police service, social capital, budget transparency, judicial independence, and effectiveness of the legal framework in challenging legislation, press freedom, legislation package and effectiveness of the legal framework. Conflict resolution, e-participation, future government orientations, corruption rate, incidence corruption, property rights, intellectual property protection, quality of land administration, conflict of interest regulations, and finally shareholder governance. Previously, the institutions indictor measured via 21 
sub-indicators until last year (i.e. 2017), and were divided into public and private institutions, and called factor-driven economics, as shown in figure 1.

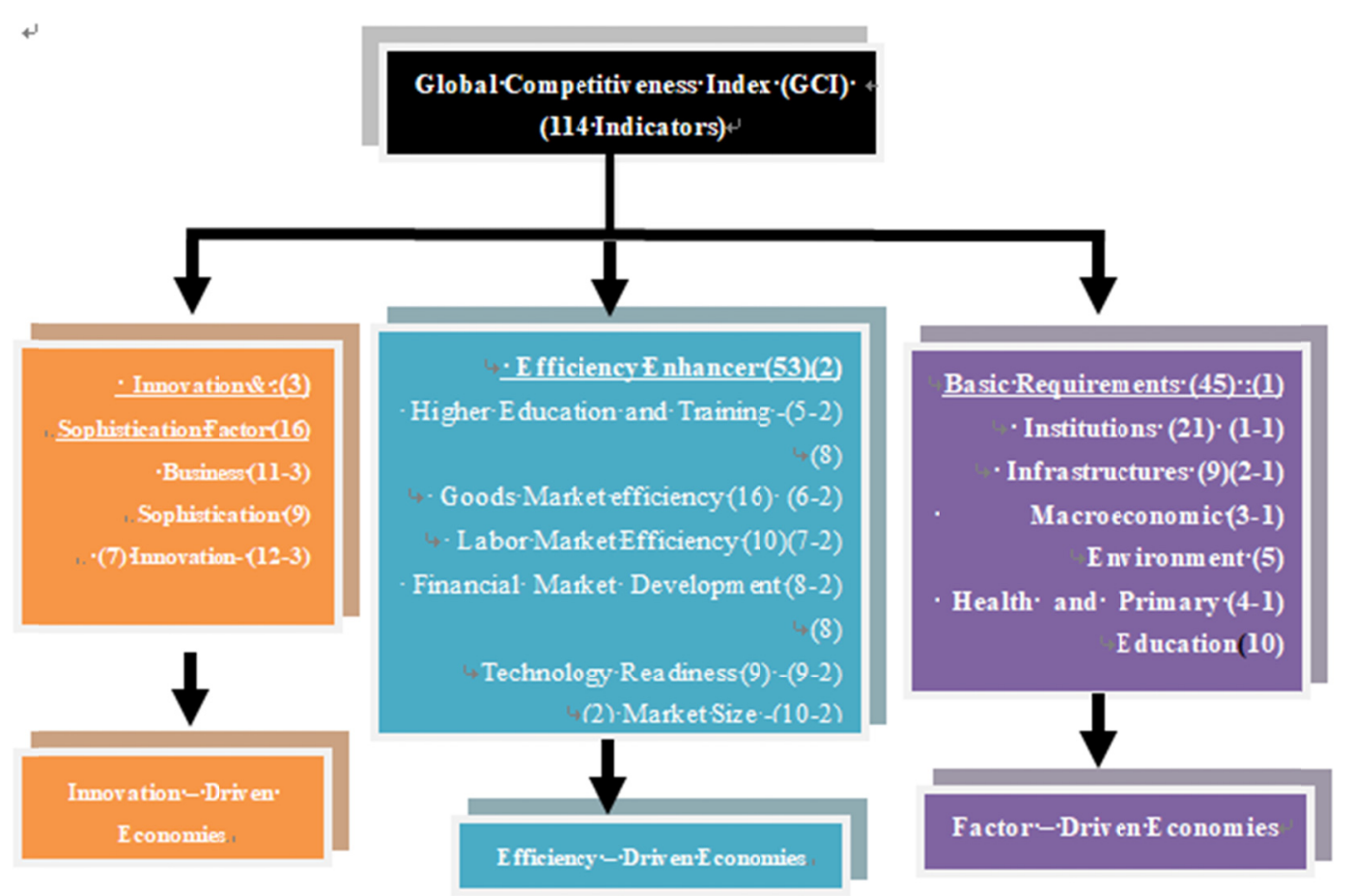

Figure 1. Components of GCI (Old)

Source: Klaus Schwab (2017).

(2) Infrastructures measured by 12 sub-indicators and previously measured by nine indicators. These sub-indicators are road connectivity index, road quality, rail density, efficiency of rail transport, air link, efficiency of air transport service, marine link index, efficiency of sea transport service, electrical coverage ratio, loss rate in the transmission and distribution of electricity, the proportion of exposure to drinking polluted water, and the reliability of the service of clean water.

(3)The adoption of information and communication technology (ICT) or what so called "knowledge economy"-is a new indicator that used at 2018 GCI report-measured by five sub-indicators: number of mobile lines, number of mobile internet subscribers, number of internet telephone subscribers, fiber net subscriptions, and the ratio of internet users to population.

(4)Macroeconomic stability, which formerly known as the macroeconomic environment and measured by five indicators, measured in 2018 report by two indicators: the annual inflation rate, and the debt dynamics. (5) Health indicator measured by only one indicator with is the healthy life expectancy. It worth mentioning that health was previously under "health and primary education indicator" that measured by five sub-indicators. (6) The skills indicator measured by nine sub- indicators: the average years of schooling, the level of workers training, the quality of professional training, the skills of graduates, the digital skills of the population, the ease of finding skilled staff, the number of years in compulsory schooling, creative thinking in teaching, and pupil-to-teacher ratio in primary education. It worth mentioning that skills-indicator was previously under "training and higher education indicator" and measured by eight sub-indicators. 


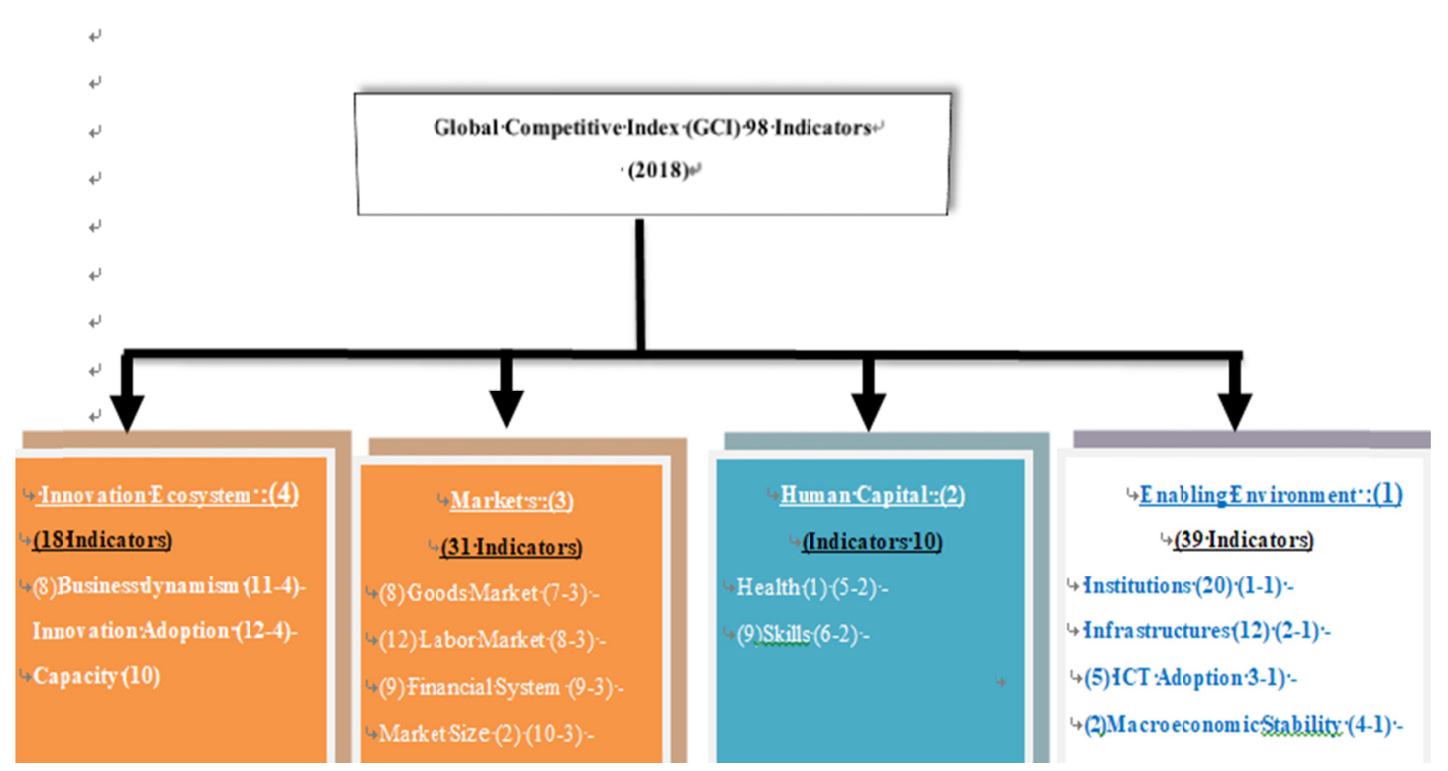

Figure 2. The new Components of GCI

Source: Klaus Schwab (2018).

(7) Product market efficiency measured by eight sub-indicators that includes distortive effect of taxes and subsidies on competition, market dominance, competition in the service sector, the prevalence of non-tariff barriers, trade tariffs, complexity of trade tariff, efficiency of the liquidation process, and openness in trade in services. Previously, efficiency of goods market measured by 16 sub-indicators, as shown in Figure (1-1). (8) Efficiency of labor market is measured by 12 sub-indicators. These are; redundancy costs, procedures for appointment and dismissal, cooperation relations between employers and workers, flexibility in determining wages, active labor policies, workers' rights, ease of employment of foreign workers, ease of movement of domestic workers, dependence on professional management, productivity-wage relationship, the percentage of female labor, and the percentage of work taxes. Before 2018, efficiency of labor market measured by 10 sub-indicators, as shown in Figure (1-1). (9)The financial system is measured by nine sub-indicators: the ratio of gross domestic product (GDP) to credit private sector, financing of small and medium-sized enterprises (SMEs), capital for new companies, market capitalization to gross domestic product (GDP), insurance premiums ratio to GDP, banks' efficiency, ratio of bad loans, credit gap, and banks capital. Before 2018, that indicator called "development of financial sector" and measured via eight sub-indicators. (10) Market size measured by two indicators: the value of GDP, and the ratio of imports to GDP. Previously, population size was a sub-indicator of market size.

(11) Business dynamics measured by eight sub-indicators: cost of start-up activity, start-up time, insolvency recovery rate, regulatory framework, trends in entrepreneurial risk, willingness to delegate authority, proportion of innovative companies, and ration of entrepreneurial companies that accept premature ideas and develop them. Previously, that indicator called sophistication business environment and measured by nine sub-indicators. (12) Innovation indicator is measured by ten sub-indicators: diversity in the labor force, development of working groups, international cooperation in innovation, cooperation between stakeholders, scientific dissemination, new innovation applications, R\&D spend ratio to GDP, quality of research institutions, degree of buyer's sophistication, and new brands used. Before 2018, innovation capacity measured by seven sub-indicators, as shown in Figure 1.

However, the main indicators remains the same in the old and updated report i.e. 12 indicators, some minor and major differences in the way of calculating, in the number of main groups, and in the number of sub-indicators for each indicator existed, as shown in the previous discussions. Therefore, comparing present with previous ranking of a country could happen, and could be valid, and sound if considering the previously mentioned slight and major differences. The same methodology used in the coming part of the current research. 
Table 1. Rank the Arab countries on the competitiveness index

\begin{tabular}{|c|c|c|c|c|c|c|c|c|c|c|c|c|}
\hline $\begin{array}{l}\text { Oman } \\
\text { (4) } \\
\mathrm{P}\end{array}$ & $\mathrm{O}$ & $\begin{array}{l}\text { KSA } \\
(3) \\
P\end{array}$ & $\mathrm{O}$ & $\begin{array}{l}\text { Qatar } \\
(2) \\
\text { P }\end{array}$ & $\mathrm{O}$ & $\begin{array}{l}\text { UAE } \\
(1) \\
P\end{array}$ & $\mathrm{O}$ & $\begin{array}{l}\text { Bahra } \\
(5) \\
\mathrm{P}\end{array}$ & $\mathrm{O}$ & $\begin{array}{l}\text { Egypt } \\
(12) \\
\text { P } \\
\text { (100 Points) }\end{array}$ & $\begin{array}{l}\mathrm{O} \\
(140)\end{array}$ & Main and Sub-indicators \\
\hline & & & & & & & & & & & & A (Enabling Environment) \\
\hline 63 & 36 & 62 & 39 & 64 & 31 & 72 & 19 & 63 & 28 & 48 & 102 & -1Institutions \\
\hline 82 & 24 & 75 & 40 & 80 & 26 & 86 & 15 & 63 & 46 & 70 & 56 & -2Infrastructures \\
\hline 57 & 61 & 60 & 54 & 82 & 9 & 84 & 6 & 70 & 33 & 41 & 100 & -3ICT Adoption \\
\hline 85 & 58 & 100 & 1 & 97 & 40 & 100 & 1 & 46 & 90 & 51 & 135 & $\begin{array}{l}\text {-4Macro Stability } \\
\text { B (Human Capital) }\end{array}$ \\
\hline 82 & 65 & 82 & 64 & 88 & 40 & 78 & 79 & 62 & 54 & 69 & 99 & -5 Health \\
\hline 72 & 36 & 73 & 30 & 71 & 38 & 68 & 53 & 36 & 72 & 53 & 99 & $\begin{array}{l}\text {-6Skills } \\
\text { C (Markets) }\end{array}$ \\
\hline 62 & 33 & 62 & 32 & 64 & 25 & 69 & 11 & 61 & 42 & 48 & 121 & -7Product Market \\
\hline 56 & 93 & 53 & 102 & 61 & 54 & 63 & 42 & 78 & 30 & 46 & 130 & -8Labor Market \\
\hline 63 & 56 & 66 & 45 & 70 & 34 & 71 & 31 & 67 & 38 & 52 & 99 & -9Financial System \\
\hline 56 & 62 & 76 & 17 & 60 & 51 & 71 & 28 & 65 & 119 & 73 & 24 & $\begin{array}{l}\text {-10Market Size } \\
\text { D (Innovation Ecosystem) }\end{array}$ \\
\hline 63 & 52 & 51 & 11 & 66 & 40 & 67 & 33 & 79 & 74 & 54 & 97 & -11Business Dynamism \\
\hline 33 & 86 & 47 & 41 & 50 & 37 & 51 & 35 & 74 & 28 & 38 & 64 & -12Innovation Capacity \\
\hline 4.28 & 66 & & & & & & & & & 643 & 1126 & Points (Total) \\
\hline 64 & 47 & 68 & 39 & 71 & 30 & 73 & 27 & 64 & 50 & 54 & 94 & (2018 Ranking) Total /(12 ) \\
\hline 61 & & 41 & & 32 & & 27 & & 46 & & 94 & & (2017 Ranking 135) Countries \\
\hline 4.28 & 66 & 4.84 & 29 & 5.23 & 18 & 5.26 & 16 & 4.47 & 48 & 115 & & (2016 Ranking 138) Countries \\
\hline 4.1 & & 32.4 & & 2.7 & & 10.1 & & 1.5 & & 94.8 & & (Population at 2018)Million \\
\hline 17.97 & & 21.1 & & 60.8 & & 37 & & 24 & & 2.5 & & (GDP Per-Capita) Thousand(\$ ) \\
\hline$\% 3.9$ & & $\% 3.5$ & & $\% 7.7$ & & $\% 2.7$ & & $\% 3.7$ & & $\% 3.9$ & & Average Growth Rate at the last 10 years \\
\hline$\% 3.3$ & & $\% 5.5$ & & $\% 0.1$ & & $\% 1.7$ & & $\% 1.2$ & & $\% 12.1$ & & Unemployment Rate \\
\hline$\% 1.2$ & & $\% 1.1$ & & $\% 0.3$ & & $\% 2.6$ & & $\% 3.9$ & & $\% 2.1$ & & Percentage of FDI to GDP \\
\hline
\end{tabular}

Notes. $\mathrm{O}=$ Country Order $\cdot \mathrm{P}=$ or from 1 -to- 7 (if the assessment before 2018) Points out of 100 (if assessment happens at 2018 ).

Table 2. Rank the Arab countries on the competitiveness index

\begin{tabular}{|c|c|c|c|c|c|c|c|c|c|c|c|c|c|c|}
\hline \multicolumn{2}{|c|}{$\begin{array}{l}\text { Yamen } \\
\text { (13) }\end{array}$} & \multicolumn{2}{|c|}{$\begin{array}{l}\text { Algeria } \\
(11)\end{array}$} & \multicolumn{2}{|c|}{$\begin{array}{l}\text { Tunisia } \\
\text { (10) }\end{array}$} & \multicolumn{2}{|c|}{$\begin{array}{l}\text { Lebanon } \\
\text { (9) }\end{array}$} & \multicolumn{2}{|c|}{$\begin{array}{l}\text { Morocco } \\
(8)\end{array}$} & \multicolumn{2}{|c|}{$\begin{array}{l}\text { Jordon } \\
(7)\end{array}$} & \multicolumn{2}{|c|}{$\begin{array}{l}\text { Kuwait } \\
\text { (6) }\end{array}$} & \multirow[t]{2}{*}{ Main and Sub-indicators } \\
\hline $\mathrm{P}$ & $\mathrm{O}$ & $\mathrm{P}$ & $\mathrm{O}$ & $\mathrm{P}$ & $\mathrm{O}$ & $\mathrm{P}$ & $\mathrm{O}$ & $\mathrm{P}$ & $\mathrm{O}$ & $\mathrm{P}$ & $\mathrm{O}$ & $\mathrm{P}$ & $\mathrm{O}$ & \\
\hline & & & & & & & & & & & & & & A (Enabling Environment) \\
\hline 29 & 139 & 44 & 120 & 52 & 75 & 45 & 113 & 57 & 54 & 58 & 50 & 56 & 57 & -1 Institutions \\
\hline 34 & 138 & 61 & 88 & 62 & 84 & 59 & 95 & 72 & 53 & 67 & 73 & 69 & 61 & -2Infrastructures \\
\hline 18 & 136 & 47 & 83 & 45 & 90 & 57 & 59 & 44 & 93 & 62 & 75 & 57 & 62 & -3ICT Adoption \\
\hline 54 & 133 & 69 & 111 & 66 & 118 & 68 & 114 & 90 & 47 & 70 & 101 & 100 & 1 & $\begin{array}{l}\text {-4Macro Stability } \\
\text { B (Human Capital) }\end{array}$ \\
\hline 50 & 120 & 81 & 66 & 83 & 58 & 88 & 37 & 75 & 88 & 78 & 78 & 88 & 38 & -5 Health \\
\hline 34 & 132 & 57 & 88 & 61 & 71 & 64 & 64 & 45 & 114 & 64 & 61 & 60 & 79 & $\begin{array}{l}-6 \text { Skills } \\
\text { C (Markets) }\end{array}$ \\
\hline 44 & 131 & 45 & 128 & 52 & 103 & 51 & 108 & 55 & 75 & 54 & 88 & 56 & 69 & -7Product Market \\
\hline 38 & 140 & 44 & 134 & 46 & 129 & 54 & 101 & 50 & 119 & 56 & 91 & 50 & 120 & -8Labor Market \\
\hline 37 & 140 & 48 & 122 & 56 & 78 & 67 & 43 & 66 & 44 & 71 & 32 & 65 & 48 & -9Financial System \\
\hline 38 & 113 & 66 & 38 & 53 & 70 & 49 & 80 & 60 & 53 & 49 & 81 & 60 & 54 & $\begin{array}{l}\text {-10Market Size } \\
\text { D (Innovation Ecosystem) }\end{array}$ \\
\hline 39 & 136 & 51 & 113 & 58 & 73 & 52 & 109 & 54 & 99 & 49 & 94 & 44 & 96 & -11Business Dynamism \\
\hline 23 & 133 & 30 & 106 & 33 & 84 & 39 & 61 & 34 & 78 & 54 & 59 & 31 & 103 & $\begin{array}{l}\text {-12Innovation Capacity } \\
\text { Points (Total) }\end{array}$ \\
\hline 39 & 139 & 54 & 92 & 56 & 87 & 58 & 80 & 75 & 75 & 59 & 73 & 62 & 54 & (2018 Ranking) Total /(12) \\
\hline 135 & & 92 & & 86 & & 75 & & 77 & & 71 & & 56 & & (2017 Ranking 135) Countries \\
\hline & 138 & 4.00 & 87 & 3.92 & 95 & 3.84 & 101 & 4.20 & 70 & 4.29 & 63 & 4.53 & 38 & (2016 Ranking 138) Countries \\
\hline 30 & & 41.5 & & 11.5 & & 4.5 & & 34.9 & & 7.1 & & 4.4 & & (Population at 2018)Million \\
\hline 0.55 & & 4.292 & & 3.496 & & 11.408 & & 3.15 & & 5.67 & & 27.31 & & (GDP Per-Capita) Thousand(\$ ) \\
\hline$-9.5 \%$ & & $\% 2.9$ & & $\% 2$ & & $\% 3.7$ & & $\% 3.9$ & & 3.2 & & $\% 1$ & & $\begin{array}{l}\text { Average Growth Rate at the last } 10 \\
\text { years }\end{array}$ \\
\hline$\% 14$ & & $\% 10.1$ & & $\% 15$ & & $\% 6.6$ & & $\% 9.3$ & & 14.9 & & $\% 2.1$ & & Unemployment Rate \\
\hline$-1.1 \%$ & & $\% 0.6$ & & $\% 2.5$ & & $\% 5.7$ & & $\% 2.8$ & & 4.9 & & $\% 0.7$ & & Percentage of FDI to GDP \\
\hline
\end{tabular}

Notes. $\mathrm{O}=$ Country Order $\cdot \mathrm{P}=$ or from 1 -to- 7 (if the assessment before 2018) Points out of 100 (if assessment happens at 2018) 


\section{Comparing amongst Arab Countries (Indicator-Based Comparisons)}

As shown in both Table 1 and 2, The Arab countries positions on GCI are as follows; UAE, Qatar, KSA, Oman, Kingdom of Bahrain, Kuwait, Jordon, Morocco, Lebanon, Tunisia, Algeria, Egypt, and Yemen in 27, 30, 39, 47, $50,54,73,75,80,87,92,94$, and 139 world places respectively at 2018 . Therefore, the current ranking of the Arab world on GCI scale is $68^{\text {th }}$ place. A place like Arab world with huge capabilities like 13 Million kilo-square and 430 million inhabitants deserves a better ranking rather than the existed ranking. It worth mentioning that India, for example, in $58^{\text {th }}$ place and USA, Singapore, Germany, Switzerland, and Japan are in places from 1 to 5 , respectively.

This part of the research will shed light on the position of each country on the twelve indicators, identifying the leading countries, taken lessons, shared experiences, and success stories to improve their country ranking in the coming taxonomy i.e. 2019. Historically, Egypt has pledged its experience and success stories in all aspects like educational, health, economic, legislative and even technical fields to the Arab countries to assist in the process of sustainable development in all aspects. Egypt has long been the benchmark in many developmental aspects for the Arab countries. It is time to rotate those accumulated experiences for all to serve all, so that the Arab world will get its proper place amongst world nations.

Nowadays, four Arab countries have success stories to be shared with others and could be used as a reference point or benchmark in sustainable development. These countries are UAE, KSA, Bahrain, and Lebanon. More specifically, UAE has six success stories in six indicators e.g. institutions, infrastructures, ICT, macroeconomic stability, product market, and financial system with $19,15,6,1,11$, and 31 world positions on GCI ranking respectively, as shown in both Tables 1 and 2. Saudi Arabia has four success stories in four GCI indicators e.g. macroeconomic stability, skills, market size, and business dynamism with 1,30,17, and 11 world positions on GCI ranking respectively, as shown in both Tables 1 and 2. The Kingdom of Bahrain has something of value to offer to Arab countries in two GCI indicators e.g. labor markets, and innovation with 30, and 28 world positions on GCI ranking respectively. Finally, Lebanon has another success story in health indicator with ranking of 37 on GCI scale. Therefore, Arab countries are invited to share these success stories of UAE in infrastructures like road network, airports, traffic services (Lotayif, 2012), logistics areas such as industrial zone in Jebel Ali, the sophisticated financial, and banking system (Lotayif, 2017). Saudi successes in areas like skills, business development, and market ought to be transferred to other Arab nations. Saudi Arabia, with a budget exceeding SR1 trillion for the second consecutive year in 2019 (revenues of SR 975 billion and expenditures SR 1106 billion). The budget deficit is $4.2 \%$ (SR 131 billion). It is worth noting that Saudi Arabia has managed to reduce the budget deficit from $12.8 \%$, to $9.3 \%$, to $4.6 \%$ and to $4.2 \%$ at $2016-2019$ respectively (Al-Jundi, 2018). The Bahraini experience should also be viewed with admiration and respect for its successes in organized and effective labor markets and innovative capabilities in all aspects of the Kingdom. Lebanon's health experience should be studied to take lessons from its outstanding successes in this perspective.

\section{Countries that have Improved Compared with Previous Classification}

By 2018, four countries out of 13 have improved their rankings over the past two years (i.e. 2016). These countries are Egypt, Lebanon, Oman, and Tunisia jumped forward by 21, 21, 19 and 8 places on GCI respectively. Egypt jumped to $94^{\text {th }}$ from $115^{\text {th }}$, Lebanon to $80^{\text {th }}$ place from 101 , Oman to 47 from $66^{\text {th }}$, and finally Tunisia to $87^{\text {th }}$ from $95^{\text {th }}$ place, as shown in Table (2). Egypt and Lebanon achieved the highest positive jumps (21 places). In the case of Egypt, this progress is due to the improvement in: (1) infrastructures (e.g. adding of $7,000 \mathrm{~km}$ to the existed road network, (2) adding $24,000 \mathrm{MW}$ to the existed electricity network, (3) the addition of the fourth generation to the existed telecommunications network), (4) the improvement in innovation capacity, and (5) progress in the pre-university education. The true impacts of these improvements in the Egyptian case will appear positively in the next report i.e. 2019. On the other hand, eight countries i.e. Kuwait, Qatar, UAE, Saudi Arabia, Jordan, Algeria, Morocco and Yemen dropped to 54, 30, 27, 39, 73, 92, 75 and 139 places at 2018 from $38,18,16,29,63,87,70$ and 138 places respectively at 2016, losing 16,12,11,10,10,5,5, and 1 places respectively, as shown in Table 3 . This does not mean their performances in sustainable development deteriorated, but definitely, it does mean there is severe competition in this regard. Consequently, all Arab countries are invited for progressing more and more to better cope with that level of severe competition in sustainable development and competitiveness. 
Table 3. Improved and declined countries by comparing the 2016-2018 ratings

\begin{tabular}{|c|c|c|c|c|c|c|c|}
\hline \multicolumn{4}{|c|}{ Countries Declined } & \multicolumn{4}{|c|}{ Countries Improved } \\
\hline Deviations & $\begin{array}{l}\text { Current } \\
\text { Ranking } \\
2018 \\
\end{array}$ & $\begin{array}{l}\text { Previous } \\
\text { Ranking } \\
2016 \\
\end{array}$ & Countries & Deviations & $\begin{array}{l}\text { Current } \\
\text { Ranking2018 }\end{array}$ & $\begin{array}{l}\text { Previous } \\
\text { Ranking } \\
2016 \\
\end{array}$ & Countries \\
\hline 16-Positions & 54 & 38 & Kuwait & $21+$ Positions & 94 & 115 & Egypt \\
\hline 12-Positions & 30 & 18 & Qatar & +21 Positions & 80 & 101 & Lebanon \\
\hline 11-Positions & 27 & 16 & UAE & 19+Positions & 47 & 66 & Oman \\
\hline 10-Positions & 39 & 29 & KSA & \multirow{5}{*}{$8+$ Positions } & \multirow{5}{*}{87} & \multirow{5}{*}{95} & \multirow{5}{*}{ Tunisia } \\
\hline 10-Positions & 73 & 63 & Jordon & & & & \\
\hline 5-Positions & 92 & 87 & Algeria & & & & \\
\hline 5-Positions & 75 & 70 & Morocco & & & & \\
\hline 1-Positions & 139 & 138 & Yemen & & & & \\
\hline
\end{tabular}

\section{Conclusions and Recommendations}

The current study is a pioneer one that assesses the progress in sustainable development using a very objective tool for that mission which is GCI report. Period's comparisons could reveal the achieved progress periodically. However, it is sometimes misleading, as you compare yourself with yourself not with other competitors. Therefore, regional and international benchmarking could help bridge this gap, as it opens avenue for valuable results by comparing oneself with the best performers, a practice that followed in the current research. For the case of Egypt, self-comparison revealed considerable level of achievements during the last two years by jumping forward 21 places. However, benchmarking scheme ranked Egypt in the 12, and 94 places Arabic and worldwide respectively. Therefore, both ways of analysis ought to be considered to get valid, sound, and reliable results. Consequently benchmarking coupled with success stories are the appropriate mechanism adopted for the rest of Arab countries. Success stories scheme is a sound mechanize in sharing sustainable development experiences amongst Arab countries. Therefore, Arab countries are invited to establish an authorized Arab council to work on sharing achieved successful stories. This council can serve as watchdog in this perspective.

Annex, every official and manager in charge in Arab countries should focus on his / her own role in enhancing his country ranking in GCI all the time. Second and third tiers of public service employees should adopt the same ideology as well. Practices in Egypt for instance revealed that those second and third tiers are often the obstacles to the proper implementation of leaders' ambitious visions and objectives. In this perspective, well orientation of junior officials help prevent all kinds of anxieties that might lead sometimes to cosmetic solutions for the sake of enhancing the country ranking. Sustainable development and long-term objectives if prevailed, the better rank inevitably will come. The case of Egypt in the last four years is an obvious example in this perspective.

\section{References}

Al-Jundi, A. (2018). The Biggest ten numbers at Saudi’s 2019 Budget.

Bondareva, I., \& Tomčík, R. (2015). Comparison of Economic Development Of The Slovak Republic And The Czech Republic Based. Global Competitiveness Index, Scientific Papers of the University of Pardubice. Series D, Faculty of Economics \& Administration.

Faur, F. D., Marchiș, C. N. (2017). Evolution Of The Coal Mining Sector In Jiu Valley In Terms Of Sustainable Development And Current Socio-Economic Implications. Research Journal of Agricultural Science, 49(4), 110-117.

Fitch. (2018). Fitch Affirms Egypt at 'B'; Outlook Positive.

IMD. (2012). IMD World Competitiveness Yearbook, Lausanne: IMD.

Isabel, M., \& Jose, M. P. L. (2013). Sustainable Development: New Research. Nova Science Publishers, Inc, New York.

Ivanová, E., \& Čepel, M. (2018). The Impact of Innovation Performance on the Competitiveness of the Visegrad 4 Countries. Journal of Competitiveness, 10(1), 54-72. https://doi.org/10.7441/joc.2018.01.04 
Kiselakova, D., Sofrankova, B., Cabinova, V. O., \& Soltesova, J. (2018). The Impact of R\&D Expenditure on The Development of Global Competitiveness Within the CEE EU Countries. Journal of Competitiveness, 10(3), 34-50. https://doi.org/10.7441/joc.2018.03.03

Klaus, S. (2017). The Global Competitiveness Report, 2016-2017. World Economic Forum.

Krstić, B., \& Džunić, M. (2013). Knowledge Economy and Competitiveness of Western Balkan Countries in the Global Economic Crisis. TEME: CasopiszaDruštveneNauke, 37(1), 141-162.

Krstic, B., Jovanovic, S., Jankovic-Milic, V., \& Stanisic, T. (2016A). Examination of travel and Tourism Competitiveness Contribution to National Economy Competitiveness of Sub-Saharan Africa Countries. Development of Southern Africa, 33(4), 470-485. https://doi.org/10.1080/0376835X.2016.1179103

Krstić, B., Stanojević, J., \& Stanišić, T. (2016B). Innovations as a Determinant of Competitiveness of Serbia: A Comparative Analysis with Western Balkan Countries and the European Union. TEME: CasopiszaDruštveneNauke, 40(3), 1035-1050.

Krugman, P. (1994). Competitiveness: A Dangerous Obsession. Foreign Affairs, 73(2), $28-44$. https://doi.org/10.2307/20045917

Lotayif, M. (2004A). GATS Impacts on Entry Modes and Defensive Marketing Strategies in the Egyptian Banking Sector. Business School, University of Plymouth, UK.

Lotayif, M. (2004B). Investigating and Modelling GATS Impacts on the Developing Countries: Evidence from the Egyptian Banking Sector. The Journal of American Academy of Business, Cambridge (JAABC), 4(1\&2), 496-502.

Lotayif, M. (2012). MBO and the First100-Days Presidency Plan. Arab Management Association (AMA), 138, 19.

Lotayif, M. (2016). Selection Factors of Market Segments and Porter's Generic Marketing Strategies: Evidence from an Emerging GCC Market. International Journal of Business and Management, 11(1), 199-215. https://doi.org/10.5539/ijbm.v11n1p199

Lotayif, M. (2017). Limits of Integration and Rivalry amongst Logistic Areas in Middle. International Politics in Al-Ahram Newspaper, 52(210), 11-16.

Lotayif, M. (2018). Empirical Assessment and Application of SERVQUAL Evidence from UAE Banks. International Journal of Business and Management, 12(4), 197-212. https://doi.org/10.5539/ijbm.v12n4p197

Lotayif, M. (2018). Environmental Scanning Mechanism and its Effects on the Performance; Evidence from UAE. International Journal of Business and Management (IJBM), 13(1), 190-208. https://doi.org/10.5539/ijbm.v13n1p190

Lotayif, M. (2018). Global Competitiveness Index's (GCI) Impacts on FDI and Tourism: Case of Egypt. Arab Management Association (AMA), 160, 20-32.

Prugh, T., Daly, H., \& Costanza, R. (2000). The Local Politics of Global Sustainability. Washington, D.C.: Island Press.

Saeed, H. A. D., \& Marwan, M. A. (2019). Developing An Organizational Design Model From The Islamic Perspective. International Journal of Current Research, 11(1), 526-533. https://doi.org/10.24941/ijcr.34213.01.2019

Schmandt, J., \& Ward, C. H. (2000). Sustainable Development: The Challenge of Transition. Cambridge, U.K.: Cambridge University Press.

Staníčková, M., \& Fojtíková, L. (2018). Status of Global Economic Powers (BRICS, EU28, Japan, USA): The Case of Competitiveness and Factors Influencing Progress or Decline.

Trading Economic. (2019). https://tradingeconomics.com/egypt/rating

\section{Copyrights}

Copyright for this article is retained by the author(s), with first publication rights granted to the journal.

This is an open-access article distributed under the terms and conditions of the Creative Commons Attribution license (http://creativecommons.org/licenses/by/4.0/). 